\title{
Initial growth of tree species grown on salinized soil with conditioners
}

\author{
Josinaldo Lopes Araujo ${ }^{*}$, Saul Ramos de Oliveira', \\ Flaubert Queiroga de Sousa², Alexandre Paiva da Silva ${ }^{2}$
'Federal University of Campina Grande, Pombal, PB, Brazil
2 Federal University of Paraíba, Areia, PB, Brazil \\ *Corresponding author, e-mail: josinaldoufcg@hotmail.com
}

\begin{abstract}
The excess of salts and sodium is one of the factors that contribute most to the soil chemical degradation. Recovery of these soils requires the establishment of techniques using soil conditioners and more tolerant species. The present study aimed to evaluate the effect of soil conditioners on the recovery of a saline - sodic soil and on the growth and physiological responses of tree species. Two experiments were carried out in a greenhouse, both using a completely randomized design. In the first experiment, five treatments were evaluated for soil correction: saline soil with no correction, saline soil + calcium sulfate, saline soil+ sulfur, saline soil + O.M. (organic matter) and non saline soil. The second experiment, consisted of a $4 \times 5$ factorial arrangement, with four trees species (Amburana cearensis, Caesalpinia ferrea, Cnidosculus philacanthus and Moringa oleifera) and the five treatments described in the first experiment, with three repetitions. Bovine manure, elemental sulfur and calcium sulfate decrease the salinity and sodicity of saline-sodic soils, especially the latter two, which attenuate the negative effects of salinity and sodicity on the photosynthetic rate of $C$. philacanthus, M. oleifera and C. ferrea, favoring the growth and dry matter production of $C$. ferrea and M. oleifera.
\end{abstract}

Keywords: alkaline soils, Caatinga biome, salinity control, salt stress

\section{Introduction}

Soils with excess of salts and sodium are characterized by high values of $\mathrm{pH}$ and exchangeable sodium percentage (ESP), low exchangeable calcium and magnesium contents and low availability of cationic micronutrients (Talei et al., 2012). These characteristics, directly or indirectly, lead to physiological and nutritional imbalances in plants, causing a decrease in their growth and development (Sousa et al., 2012; Sá et al., 2015; Araujo et al., 2015). Therefore, to recover the areas productivity it is essential to use techniques that improve these soils fertility (Uddin et al., 2011; Araujo et al., 2015).

In the recovery of these soils, products such as organic residues, calcium chloride, agricultural gypsum, sulfuric acid and elemental sulfur are considered the most efficient (Fuente et al., 2007; Zia et al., 2007; Leal et al., 2008; Gharaibeh et al., 2009; Golldack et al., 2011; Sousa et al., 2012, sá et al., 2013; Ahmad et al., 2013; Souza et al., 2014). However, the use of tree species more tolerant to salts can contribute to the recovery process of these areas (Qadir et al., 2007; Araujo et al., 2015). In general, native species are adapted to the severe climatic conditions of the semi-arid region, and can be an important alternative for the recovery and use of salinized areas or in salinization processes (Qadir, 2007). In addition, these species are of 
multiple use, have deep root systems, increase permeability, soil porosity, assist in the lowering of the water table, and reduce the risks of soil salinization (Gill et al., 2009).

The species Amburana Cearensis, Caesalpinia ferrea and Cnidosculus philacanthus are nativeof the Caatinga biome and suffer deforestation, mainly for use as firewood in potteries and bakeries in the semiarid region (Lorenzi, 2000). The Moringa oleifera is a tree species probably from India and adapted in the region (Lorenzi, 2000), presenting fast growing and has been used in animal feed. Although they are species with economic potential and adapted to the stressful conditions of the Brazilian semiarid, there is little or no information about the tolerance of these species to salinity and sodicity (Sousa et al., 2012).

Thus, the aim of this study was to evaluate the effect of conditioners on the recovery of a saline-sodium soil of the semiarid region of the Paraiba State and the effect on the growth and physiological responses of four tree species, occurring in the Caatinga biome.

\section{Material and Methods}

Two experiments were conducted in a protected environment of the Campina Grande Federal University, Center for Food, Agricultural Science and Technology (CCTA), Campus of Pombal-PB, Brazil $16^{\circ} 47^{\prime} 3,97$ "S, 37²4'6,80"W and $193 \mathrm{~m}$ ) from December 2012 to May, 2013. Samples of a saline-sodic soil and a non-saline soil, both classified as Fluvic Neossol (Embrapa, 2013), were used. Samples were randomly obtained at depth of $0-40 \mathrm{~cm}$, in an area belonging to the fruit growing sector of the Irrigated Perimeter of São Gonçalo, located $10 \mathrm{~km}$ from the municipality of Sousa-PB, Brazil. After dried in air, the samples were sent to the Laboratory of Soils and Plant Nutrition of the CCTA/UFCG for their chemical and physical characterization (Table 1), according to the methodology proposed by Embrapa (2011).

Table 1. Chemical and physical attributes of soil samples of the first experiment.

\begin{tabular}{|c|c|c|c|c|c|c|c|c|c|}
\hline Soils & $\mathrm{pH} \mathrm{CaCl}$ & $\mathrm{CSe}$ & $\mathrm{P}$ & $\mathrm{K}$ & $\mathrm{Na}$ & $\mathrm{Ca}$ & $\mathrm{Mg}$ & $\mathrm{H}+\mathrm{Al}$ & ESP \\
\hline & & $\mathrm{dSm} \mathrm{m}^{-1}$ & $\mathrm{mg} \mathrm{dm}^{-3}$ & \multicolumn{5}{|c|}{ - } & $\%$ \\
\hline Saline-sodic & 10.7 & 16.8 & 5.8 & 0.20 & 11.38 & 0.5 & 0.6 & 0.0 & 89.0 \\
\hline \multirow[t]{3}{*}{ Non-saline } & 8.0 & 0.8 & 8.2 & 0.98 & 1.19 & 4.0 & 2.9 & 0.0 & 12.0 \\
\hline & Sand & Silt & Clay & \multicolumn{3}{|c|}{ Moisture at $0.033 \mathrm{Mp}$} & DS & $\mathrm{Dp}$ & \\
\hline & & & \multicolumn{4}{|l|}{$--g k^{-1}--$} & \multicolumn{2}{|c|}{$---\mathrm{gcm}^{-3}---$} & \\
\hline Saline-sodic & 622 & 140 & 238 & & 66.9 & & 1.45 & 2.64 & \\
\hline Non-saline & 775 & 67 & 158 & & 69.4 & & 1.48 & 2.61 & \\
\hline
\end{tabular}

In the first experiment, a completely randomized design was used with five treatments according to the use of soil conditioners (without correction, calcium sulfate, elemental sulfur, organic matter and non-saline soil) with 12 replicates, totaling 60 pots with $6.0 \mathrm{dm}^{3}$ of soil each.

The dose of calcium sulfate p.a (11.76 g $\mathrm{kg}^{-1}$ ) was determined as suggested by Leite et al. (2007) using the formula NG $=0.86 \mathrm{Na}+x /$ calcium sulphate purity, where: $N G=$ need for gypsum in $\mathrm{g} \mathrm{kg}^{-1}$ soil, $\mathrm{Na}+\mathrm{x}=$ exchangeable sodium content in $\mathrm{cmol}_{c} \mathrm{dm}^{-3}$. For elemental sulfur, an analytical product (p.a) was used and its dose was calculated based on the recommended dose of gypsum, in order to provide the same amount of sulfur supplied by calcium sulfate.
For the organic matter, the bovine manure was used in the dose corresponding to $15 \%$ of the soil volume. The manure used was purchased from growers of the region and exposed to the climatic conditions of the period. This organic material contained $19.0 \mathrm{~g} \mathrm{~kg}^{-1}$ of $\mathrm{N} ; 7.59 \mathrm{~g} \mathrm{~kg}^{-1}$ of $\mathrm{P} ; 4.60$ $\mathrm{g} \mathrm{kg}^{-1}$ of K; $260 \mathrm{~g} \mathrm{~kg}^{-1} \mathrm{C}$ and $0.40 \mathrm{~g} \mathrm{~kg}^{-1} \mathrm{Na}$. The materials were incorporated and homogenized to the soil volume contained in each pot.

After the application of the conditioners, the soils were maintained for 30 days with humidity corresponding to $70 \%$ of the field capacity. Than the soil was washed, applying a volume of water equivalent to twice the total porosity of the soil. The water used for washing had an EC average of $0.28 \mathrm{dS} \mathrm{m}^{-1} \mathrm{~cm}$ at $25^{\circ} \mathrm{C}$. After washing, from four of the 12 pots of each treatment, $100 \mathrm{~g}$ of 
soil were removed to perform a new chemical characterization of the soil, according to the previously described procedures.

The second experiment was a continuation of the first one and the same 60 pots containing the five treatments of soil correction of the previous experiment were used. The experiment was carried out in a completely randomized design, with treatments consisting of a $4 \times 5$ factorial scheme, with four tree species: Amburana cearensis, Caesalpinia ferrea, Cnidosculus philacanthus, combined with the five treatments tested in the first experiment, with three replicates totaling 60 experimental units. The seeds of the species were germinated in 300 $\mathrm{mL}$ tubes filled with non-saline soil and bovine manure in the proportion of $3: 1(v / v)$. After reaching about $15 \mathrm{~cm}$ in height, the seedlings were selected and transferred to the pots with the soils already washed, that is, after the leaching of the salts, with the respective treatments.

After 15 days after transplanting it was evaluated, through a non-destructive method the transpiration rate, photosynthetic rate, stomatal conductance and intercellular $\mathrm{CO}_{2}$ concentration in the plants by non-destructive method using the infra-red gas analyzer (Infra-red Gas Analyzer, portable, open system, Li-Cor LI$6400 X T$ model). The measured of these variables were realized in the leaves of the middle third of each plant of each treatment under full sun, from 8:00 a.m. to 10:00 p.m.. After 75 days of transplanting, the plant diameter and plant height were measured. Then, the aerial parts of the plants were separated from the roots and dried in an oven at $65-70^{\circ} \mathrm{C}$ to obtain the shoot dry mass (SDM) and root dry mass (RDM). With the values of plant height, stem diameter, MSR and MSPM, were estimated the relative growth in height, relative growth in diameter, relative production of MSPM and MSR, correlating the values of these variables, obtained in the saline soil (with or without correction) with those obtained in the non-saline soil.

In order to diagnose a significant effect of the treatments by the F's test, the data were submitted to analysis of variance (ANOVA) and the means were compared by the Tukey's test, both tests being performed at $5 \%$ probability using the SISVAR ${ }^{\circledR}$ software (Ferreira, 2011).

\section{Results}

All soil chemical attributes were affected by soil correction treatments (Table 2). The application of the conditioners provided to the saline-sodic soils decreases in $\mathrm{pH}$ values, in $\mathrm{EC}_{1: 5}$ (electrical conductivity obtained in the soil: water ratio 1:5), exchangeable $\mathrm{Na}^{+}$, ESP levels and elevation in exchangeable $\mathrm{Ca}$ and $\mathrm{Mg}$ (Table 2). The exchangeable contents of $\mathrm{K}^{+}$were higher in the non-saline soil treatments and in the saline soil treatment treated with organic matter. For non-saline soils, higher values were observed, probably due to their initial values, that is, before the application of the treatments (Table 1). In the case of treatment with organic matter, the highest values of $\mathrm{K}^{+}$may have been due to its fast release by organic matter, since this element is not part of organic compounds. Among the conditioners, the elemental sulfur was the one that reduced the ESP and in the soil sodium contents, although it resulted in lower levels of exchangeable calcium than the calcium sulfate.

The values of $\mathrm{CE}, \mathrm{pH}, \mathrm{K}^{+}$and $\mathrm{Na}^{+}$, obtained from the saturation extract were lower in the saline-sodic soil with the application of the conditioners (Table 3). However, when compared to the non-saline soil, the values remained high. In the decrease of the salinity of the saturation extract (CEes), the treatments with O.M. (Tables 2 and 3) stood out. This fact is probably due to the improvement of the soil physical structure, providing a greater permeability of the water and allowing higher salts leaching (Souza et al., 2014).

Regarding the physiological variables, it is possible to observe that the photosynthetic rate, with the exception of the Amburana cearensis species, was higher in the saline soil with sulfur, but did not differ from the non-saline soil (Table 4). According to the same table, the saline soil without correction provided the lowest values for this variable.

The values of transpiration rate and stomatal conductance of the Cnidosculus philacanthus and Moringa oleifera species were higher in saline soils treated with calcium sulphate or elemental sulfur and in non-saline soil 
Table 2. Chemical attributes of the soil sorption complex used in the first experiment, after application of the treatments and the salt leaching layer.

\begin{tabular}{lccccccc}
\hline \multicolumn{1}{c}{ Treatment } & $\mathrm{PHCaCl}_{2}$ & $\mathrm{CE}_{1: 5}$ & $\mathrm{~K}^{+}$ & $\mathrm{Na}^{+}$ & $\mathrm{Ca}^{2+}$ & $\mathrm{Mg}^{2+}$ & $\mathrm{ESP}$ \\
\hline Saline without corrective & $9.4 \mathrm{a}$ & $0.83 \mathrm{a}$ & $0.60 \mathrm{~b}$ & $10.2 \mathrm{a}$ & $0.67 \mathrm{~d}$ & $0.56 \mathrm{c}$ & $88.15 \mathrm{a}$ \\
Saline $+\mathrm{CaSO}_{4}$ & $7.5 \mathrm{C}$ & $0.58 \mathrm{~b}$ & $0.42 \mathrm{~b}$ & $4.27 \mathrm{~b}$ & $5.20 \mathrm{a}$ & $2.52 \mathrm{ab}$ & $34.10 \mathrm{~b}$ \\
Saline + sulfur & $7.3 \mathrm{C}$ & $0.40 \mathrm{~b}$ & $0.66 \mathrm{~b}$ & $2.33 \mathrm{C}$ & $3.30 \mathrm{~b}$ & $2.40 \mathrm{ab}$ & $26.49 \mathrm{~b}$ \\
Saline + O.M. & $8.5 \mathrm{~b}$ & $0.56 \mathrm{~b}$ & $0.98 \mathrm{a}$ & $6.01 \mathrm{~b}$ & $2.40 \mathrm{c}$ & $0.60 \mathrm{c}$ & $43.31 \mathrm{~b}$ \\
Non saline & $7.2 \mathrm{C}$ & $0.12 \mathrm{C}$ & $1.07 \mathrm{a}$ & $1.19 \mathrm{C}$ & $4.78 \mathrm{ab}$ & $2.90 \mathrm{a}$ & $12.08 \mathrm{C}$ \\
$\mathrm{CV}(\%)$ & 1.9 & 34.8 & 31.8 & 29.7 & 25.34 & 36.2 & 35.4 \\
\hline Means followed by the same letter are not different according to Tukey's test at $5 \%$ of probability. ESP- exchangeable sodium percentage; $\mathrm{EC}_{1.5}$ electrical conductivity
\end{tabular}
of the soil:water ratio 1:5; O.M.- organic matter; CV- Coefficient of variation.

Table 3. Chemical attributes of the saturation extract of soils of the first experiment after the application of the treatments and the salt leaching layer.

\begin{tabular}{|c|c|c|c|c|}
\hline Treatments & cse & pHes & $\mathrm{K}^{+}$ & $\mathrm{Na}^{-}$ \\
\hline & $\mathrm{dSm}^{-1}$ & \multicolumn{3}{|c|}{ 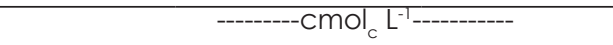 } \\
\hline Saline without corrective & $6.68 a$ & $10.05 a$ & $0.16 b$ & $6.11 \mathrm{a}$ \\
\hline Saline $+\mathrm{CaSO}_{4} 2 \mathrm{H}_{2} \mathrm{O}$ & $4.63 \mathrm{~b}$ & $8.22 \mathrm{c}$ & $0.09 \mathrm{c}$ & $3.60 \mathrm{~b}$ \\
\hline Saline + sulfur & $5.04 \mathrm{ab}$ & $8.25 c$ & $0.09 \mathrm{c}$ & $3.73 b$ \\
\hline Saline +O. M. & $2.42 \mathrm{c}$ & $9.24 \mathrm{ab}$ & $0.07 c$ & $2.72 \mathrm{bc}$ \\
\hline Non saline & $0.87 d$ & $7.29 \mathrm{~d}$ & $0.29 a$ & $2.17 c$ \\
\hline CV (\%) & 16.27 & 1.29 & 14.36 & 16.35 \\
\hline
\end{tabular}

Means followed by the same letter are not different according to Tukey's test at $5 \%$ of probability. CSe- electrical conductivity of the saturation extract; O.M.organic matter; CV- Coefficient of variation.

Table 4. Physiological variables of the tree species according to the soil correction treatments of the first experiment.

\begin{tabular}{|c|c|c|c|c|}
\hline Soil correction & $\begin{array}{c}\text { Amburana } \\
\text { cearensis }\end{array}$ & $\begin{array}{l}\text { Cnidosculus } \\
\text { philacanthus }\end{array}$ & Moringa oleifera & Caesalpinia ferrea \\
\hline \multicolumn{5}{|c|}{ Net photosyntesis $\left(\mu \mathrm{mol} \mathrm{m} \mathrm{m}^{-2} \mathrm{~s}^{-1}\right)$} \\
\hline Saline without correction & $2.53 \mathrm{aA}$ & $1.43 \mathrm{CB}$ & $1.19 \mathrm{CB}$ & $2.68 \mathrm{bA}$ \\
\hline Saline $+\mathrm{CaSO}_{4} 2 \mathrm{H}_{2} \mathrm{O}$ & $2.88 \mathrm{aC}$ & $7.63 \mathrm{bB}$ & $12.30 \mathrm{bA}$ & $4.40 \mathrm{bc}$ \\
\hline Saline + sulfur & $2.46 \mathrm{aD}$ & $11.78 \mathrm{aB}$ & $17.83 \mathrm{aA}$ & $9.08 \mathrm{aC}$ \\
\hline Saline + O.M. & $1.26 \mathrm{aB}$ & $1.83 \mathrm{CB}$ & $0.95 \mathrm{CB}$ & $3.98 \mathrm{bA}$ \\
\hline Non-saline & $3.91 \mathrm{aD}$ & $13.69 \mathrm{aA}$ & $11.03 \mathrm{bB}$ & $7.15 \mathrm{aC}$ \\
\hline \multicolumn{5}{|c|}{ Stomatal conductance $\left(\mathrm{mol} \mathrm{m}^{-2} \mathrm{~s}^{-1}\right)$} \\
\hline Saline without correction & $0.03 \mathrm{aA}$ & $0.03 \mathrm{cA}$ & $0.04 \mathrm{cA}$ & $0.03 \mathrm{bA}$ \\
\hline Saline $+\mathrm{CaSO}_{4} 2 \mathrm{H}_{2} \mathrm{O}$ & $0.03 \mathrm{aB}$ & $0.09 \mathrm{bB}$ & $0.17 \mathrm{bA}$ & $0.05 \mathrm{bB}$ \\
\hline Saline + sulfur & $0.02 \mathrm{aC}$ & $0.17 \mathrm{aB}$ & $0.42 \mathrm{aA}$ & $0.14 \mathrm{aB}$ \\
\hline Saline + O.M. & $0.05 \mathrm{aA}$ & $0.03 c A$ & $0.03 \mathrm{cA}$ & $0.04 \mathrm{bA}$ \\
\hline Non-saline & $0.06 \mathrm{aB}$ & $0.19 \mathrm{aA}$ & $0.14 \mathrm{bA}$ & $0.07 \mathrm{bB}$ \\
\hline \multicolumn{5}{|c|}{ Transpiration $\left(\mathrm{mmol} \mathrm{m}^{-2} \mathrm{~s}^{-1}\right)$} \\
\hline Saline without correction & $0.77 \mathrm{aA}$ & $0.96 \mathrm{cA}$ & $0.97 \mathrm{dA}$ & $0.85 \mathrm{aA}$ \\
\hline Saline $+\mathrm{CaSO}_{4} 2 \mathrm{H}_{2} \mathrm{O}$ & $0.78 \mathrm{aB}$ & $2.49 \mathrm{bA}$ & $3.11 \mathrm{bA}$ & $1.31 \mathrm{aB}$ \\
\hline Saline + sulfur & $0.72 \mathrm{aC}$ & $3.83 \mathrm{aB}$ & $4.32 \mathrm{aA}$ & $1.87 \mathrm{aC}$ \\
\hline Saline + O.M. & $1.10 \mathrm{aA}$ & $0.97 \mathrm{cA}$ & $0.65 \mathrm{dA}$ & $1.02 \mathrm{aA}$ \\
\hline Non-saline & $1.10 \mathrm{aC}$ & $3.40 \mathrm{aA}$ & $2.67 \mathrm{CB}$ & $1.30 \mathrm{AC}$ \\
\hline \multicolumn{5}{|c|}{ Intercellular concentration of $\mathrm{CO}_{2}\left(\mathrm{mg} \mathrm{L}^{-1}\right)$} \\
\hline Saline without correction & $199.6 \mathrm{bB}$ & $250.0 \mathrm{aA}$ & $247.3 \mathrm{aA}$ & $207.3 \mathrm{aB}$ \\
\hline Saline $+\mathrm{CaSO}_{4} 2 \mathrm{H}_{2} \mathrm{O}$ & $214.3 \mathrm{bA}$ & $190.3 \mathrm{bA}$ & $200.0 \mathrm{bA}$ & $207.0 \mathrm{aA}$ \\
\hline Saline + sulfur & $213.3 \mathrm{bA}$ & $204.3 \mathrm{bA}$ & $233.0 \mathrm{aA}$ & $225.0 \mathrm{aA}$ \\
\hline Saline + O.M. & $246.6 \mathrm{aA}$ & $268.3 \mathrm{aA}$ & $248.3 \mathrm{aA}$ & $178.3 \mathrm{aB}$ \\
\hline Non-saline & $242.6 \mathrm{aA}$ & $186.3 \mathrm{CA}$ & $195.3 \mathrm{bA}$ & $213.3 \mathrm{aA}$ \\
\hline
\end{tabular}

(Table 4). The intercellular concentration of $\mathrm{CO}_{2}$ in turn, did not follow this same tendency, and for the Caesalpinia ferrea species, no difference was observed between the treatments of soil correction. For the Amburana cearensis species the soil correction treatments did not affected the physiological variables, except for the intercellular $\mathrm{CO}_{2}$ concentration, in which the 
highest values were obtained in the treatment with O.M., but without differing from the nonsaline soil treatment. By the same table, when comparing the species, it was observed that the Cnidosculus philacanthus and Moringa oleifera were the ones that presented the highest values for the physiological variables, except for the intercellular $\mathrm{CO}_{2}$ concentration.

Regarding the plants height (growth), a varied response was observed to the treatments of soil correction according to the vegetal species (Figure 1). For Amburana cearensis (Figure 1A), the highest growth in height occurred

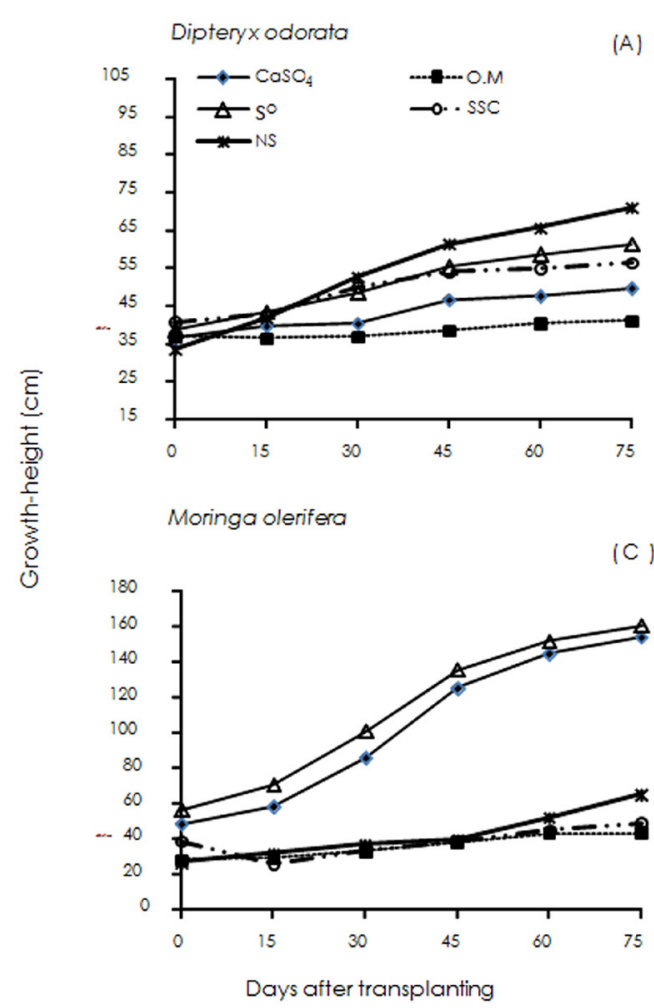

in non-saline soil followed by elemental sulfur. With the exception of the cited species (Figure 1), the highest growth of plants was provided by elemental sulfur followed by calcium sulfate. The Cnidosculus philacanthus species (Figure 1D) obtained higher growth in the non-saline soil up to 45 days after transplanting. After this period, elemental sulfur provided better performance of the species. Among the studied species, the highest growth in height was obtained by Moringa oleifera and Caesalpinia ferrea, especially when grown in saline soil treated with elemental sulfur (Figure 1).

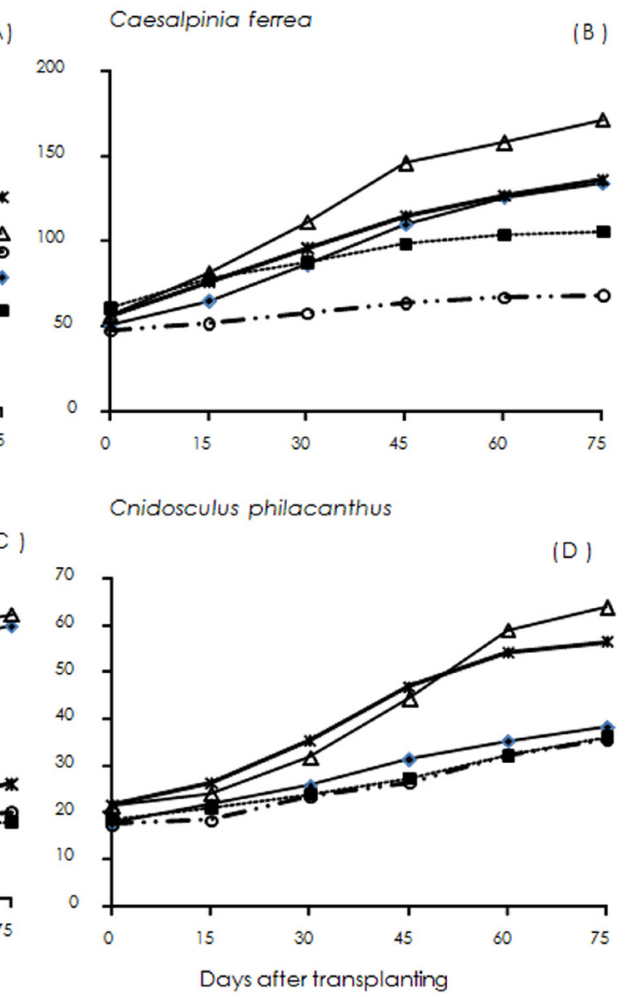

Figure 1. Growth in height of plant species according to the soil treatments. SSC- without correction; $\mathrm{CASO}_{4}$ - corrected with calcium sulfate; $\mathrm{S}^{\circ}$ - corrected with elemental sulfur; O.M- with organic matter; NS- non-saline soil.

The highest values of relative height / growth (Figure 2A) and diameter (Figure 2B) of the plant species were obtained by applying elemental sulfur or calcium sulfate. It was observed that the species Amburana cearensis was the most sensitive to salinity in relation to the relative growth in height (Figure 1A), especially in the treatment with organic matter. For both variables the Moringa oleifera and the Caesalpinea ferrea stood out (Figure 1).

The highest values for relative shoot dry mass (RSDM) (Figure 2C) and relative root dry mass (RRDM) (Figure 2D) were obtained by applying elemental sulfur or calcium sulfate to the soil. Regardless the species, the application of elemental sulfur provided values for these variables of at least $75 \%$. Comparing the plant species, it was observed that, for RSDM (Figure 2C), the Moringa oleifera and Caesalpinia ferrea species stood in with the treatments calcium sulfate and elemental sulfur treatments, however, they obtained the smallest responses in the other treatments, both for RSDM (Figure 1C) and for RRDM (Figure 2D). 


\section{Discussion}

The reduction of the ESP by the application of calcium sulfate or elemental sulfur is mainly due to the sodium displacement of the exchange complex by the calcium released by the conditioners (Sadiq et al., 2007). In this process, the sodium is displaced to the soil solution to react with the sulfate anions, forming sodium sulfate that is removed after the application of a water slide (Leite et al., 2007). As for sulfur, its effect on $\mathrm{pH}$ lowering of saline soil is probably due to the biological oxidation of elemental sulfur, which produces acidity and sulfate in the soil (Stamford et al., 2007; Heydarnezhad et al., 2012; Sá et al., 2013). The acidity generated by the oxidation of sulfur possibly contributed to increase the minerals solubility such as calcium carbonate and/or magnesium and mainly calcium and potassium feldspar increasing the concentration of exchangeable cations such as calcium, magnesium and potassium, also contributing to the reduction of the soil ESP. Calcium sulfate, despite having no acid reaction, also reduced the $\mathrm{pH}$ of the saline-sodic soil. This decrease occurs indirectly, due to the decrease of the exchangeable sodium contents (Miranda et al., 2011 ; Sousa et al., 2012; Sá et al., 2013).

In turn, the addition of organic matter, although in some cases had a positive effect on the growth and production of plants dry mass, produces a less pronounced effect than the other conditioners. The organic residues can physically improve the soil, providing a greater aggregation and increasing its macroporosity, facilitating the removal of the soluble salts (Gill et al., 2009; Makoi \& Verplancke, 2010). However, these materials did not contribute to the removal of exchangeable sodium as much as calcium sulfate and elemental sulfur, since the amounts of exchangeable cations released from their mineralization are insufficient for the displacement of exchangeable sodium from the exchange complex (Gill et al., 2009; Miranda et al., 2011).

The reductions in the photosynthetic rate, transpiration rate and stomatal conductance with elevated salinity and sodic levels are attributed to water stress (Tejada et al., 2006; Alves et al., 2009), which causes closure of the stomata and reduces de $\mathrm{CO}_{2}$ flow into the cell, as well as the toxic effect of the sodium excess (Munns, 2002; Velinni et al., 2008; Fernandes et al., 2010; Uddin et al., 2011; Souza et al., 2012).

It should be pointed out that in the case of the species Amburana cearensis, the absence of a difference between the soil conditioners, for the photosynthetic rate (Table 4), could indicate a greater tolerance of this species to the salt stress. However, this effect was not necessarily reflected in the production of relative dry mass, mainly of aerial part. It is possible that for the cited species, these physiological variables are not good indicators of tolerance to the salinity or can mean that due to the growth in a saline environment, the plant has adjusted to the stressful conditions. Sousa et al. (2012) observed that the reduction of the photosynthetic rate was correlated with the increase of the sodium content and reduction of the potassium/sodium ratio in the aerial part of native Caatinga tree species. Similarly, Uddin et al. (2011) observed a reduction in chlorophyll content in several grass species under salt stress. Thus, the application of these conditioners to the soil could reduce the stressing effects to these species provided by the excess of salts and sodium in the soil.

The decrease of the relative growth of plants and the relative production of dry mass in the saline-sodic soils without corrective occurred probably due to the higher concentration of sodium in the soil, causing toxicity to the plants and due to the higher saline concentration and resulting in a lower osmotic potential of the soil solution, causing water stress in the plants (Mendonça et al., 2007, Fernandes et al., 2010). In addition, it is likely that the excess of sodium in the soil without a corrective may have caused competitive inhibition with potassium and calcium, thus contributing to decrease of plant growth, as observed by Uddin et al. (2011).

Regarding the shoot production, Caesalpinia ferrea and Moringa oleifera species seem to be the ones with the highest potential use in soils with salt excess and sodium when associated with the use of elemental sulfur or calcium sulfate conditioners. The other species presented fast growth (Sousa et al., 2012). Regarding the dry mass relative to the 
photosynthetic rate, the Moringa oleifera and Cnidosculus philacanthus species stood out in soils without correction. However, Cnidosculus philacanthus produced less than half of the dry mass when compared to the non-saline soil, with a limited potential without the use of soil conditioners.

Therefore, the beneficial effect of the treatments on the growth of the studied species can be explained by the better soil chemical conditions when treated with elemental sulfur or calcium sulphate (Tables 2 and 3 ).

\section{Conclusions}

Bovine manure, elemental sulfur or calcium sulfate decreases the salinity and the sodicity of saline-sodic soils, with calcium sulfate and elemental sulfur showing better results.

Calcium sulfate and elemental sulfur decrease the negative effects of salinity and sodicity on the photosynthetic rate of the Caesalpinia ferrea, Cnidosculus philacanthus and Moringa oleifera species, favoring the initial growth, mainly for Caesalpinia ferrea and Moringa oleifera species.

It should be emphasized that the results of the present study were obtained in a protected environment, requiring studies in the field for validation. It is suggested that future studies evaluate other management situations and/or other soil conditioning products, as well as an evaluation of the soil physical attributes.

\section{References}

Ahmad, S., Ghafoor, A., Akhtar, M.E., Khan, M.Z. 2013. Ionic displacement and reclamation of saline-sodic soils using chemical amendments and crop rotation. Land Degradation \& Development 24:170-178.

Alves, F.A.L., Siva, S.L.F., Silveira, J.A.G.; Pereira, V.L.A. 2009. Mecanismos fisiológicos envolvidos com a diminuição de $\mathrm{K}^{+}$em raízes de cajueiro causada por $\mathrm{NaCl}$. Revista Ciência Agronômica 40:588-595.

Araujo, J.L., Severo, P.J.S., Lucena, F.T.C., Veriato, R.G. 2015. Enxofre elementar ou sulfato de cálcio para remediação de solos salino-sódicos? Pesquisa Agropecuária Tropical 4:388-396.

EMBRAPA - Empresa Brasileira de Pesquisa Agropecuária. Centro Nacional de Pesquisas de Solos. 2011. Manual de métodos de análises de solos. $2^{\mathrm{a} e d .}$ Embrapa Solos, Rio de Janeiro, Brasil. 230p.

EMBRAPA. Empresa Brasileira Pesquisa agropecuária. Sistema brasileiro de classificação de solos. 2013. 3.ed. Embrapa Solos, Rio de Janeiro, Brasil.353p.

Fernandes, O.B., Pereira, F.H.F., Andrade Júnior, W.P., Queiroga, R.C.F., Queiroga, F. M. 2010. Efeito do nitrato de cálcio na redução do estresse salino no meloeiro. Revista Caatinga 23:93-103.

Ferreira, D.F. Sisvar: a computer statistical analysis system. 2011. Ciência \& Agrotecnologia 35:10391042.

Fuente, R.G., Carrión, C.; Botella, S., Fornes, F., Noguera, V., Abad, M. 2007. Biological oxidation of elemental sulfur added to three composts from different feedstocks to reduce their $\mathrm{pH}$ for horticultural purposes. Bioresource Technology 98: 3561-3569.

Gharaibeh, M.A., Eltaif, N.I., Shunnar, O.F. 2009. Leaching and reclamation of calcareous salinesodic soil by moderately saline and moderateSAR water using gypsum and calcium chloride. Journal Plant Nutrition Soil Science 172: 713-719.

Gill, J.S., Sale, P.W.G., Peries, R.R., C. Tang, C. 2009. Changes in soil physical properties and crop root growth in dense sodic subsoil following incorporation of organic amendments. Field Crops Research 114: 137-146.

Golldack, D., Lüking, I., Yang, O. 2011. Plant tolerance to drought and salinity: stress regulating transcription factors and their functional significance in the cellular transcriptional network. Plant Cell Reports 30: 1383-1391.

Heydarnezhad, F., Shahinrokhsar, P., Vahed, H.S., Besharati, H. 2012. Influence of elemental sulfur and sulfur oxidizing bacteria on some nutrient deficiency in calcareous soils. International Journal Agriculture and Crop Science 4:735-739.

LeaL, I.G., Accioly, A.M.A., Nascimento, C.W.A., Freire, M.B.G.S., Montenegro, A.A.A., Ferreira, F.L. 2008. Fitorremediação de solo salino sódico por Atriplex nummularia e gesso de jazida. Revista Brasileira de Ciência do Solo 32: 1065-1072.

Leite, E.M., Cavalcante, L.F.C., Diniz, A.A., Santos, R.V., Alves, G.S., Lucena, Cavalcante, I.H.L. 2007. Correção da sodicidade de dois solos irrigados em resposta à aplicação de gesso agrícola. Irriga 12: 168-176.

Lorenzi, H. 2000. Árvores brasileiras: manual de identificação e cultivo de plantas arbóreas do Brasil. Instituto Plantarum, Nova Odessa, Brasil. 373p. 
Makoi, J.H.J.R., Verplancke, H. 2010. Effect of Gypsum Placement on the Physical Chemical Properties of a Saline Sandy Loam Soil. Australian Journal of Crop Science 4: 556-563.

Mendonça, A.V.R., Carneiro, J.G.A., Barroso, D.G., Santiago, A.R., Rodrigues, L.A. R., Freitas, T.A.S. 2007. Características biométricas de mudas de Eucalyptus sp sob estresse salino. Revista Árvore 31: 365-372.

Miranda, M.A., Oliveira, E.E.M., Santos, K.C.F., Freire, M.B.G.S., Almeida, B.G. 2011. Condicionadores químicos e orgânicos na recuperação de solo salino-sódico em casa de vegetação. Revista Brasileira de Engenharia Agrícola e Ambiental 15: 484-490.

Munns, R. 2002. Comparative physiology of salt and water stress. Plant, Cell and Environment 25 $239-250$

Qadir, M. 2007. Phytoremediation of sodic and saline-sodic soils. Advances in Agronomy 96: 197 247.

Sá, F.V.S., Araújo, J.L., Novaes, M.C., Oliveira, S.R. 2013b. Crescimento inicial de craibeira em solo salinizado corrigido com enxofre elementar. Irriga 18: 647-660.

Sá, F.V.S., Araujo, J.L., Novaes, M.C., Silva, A.P., Pereira, F.H.F., Lopes, K.P. 2013b. Crescimento inicial de arbóreas nativas em solo salino-sódico do nordeste brasileiro tratado com corretivos. Revista Ceres 3: 388-396.

Sadiq, M., Hassan, G., Mehdi, S.M., Hussain, N., Jamil, M. 2007. Amelioration of saline-sodic soils with tillage implements and sulfuric acid application. Pedosphere 17: 182-190.

Sousa, F.Q., Araújo, J.L., Silva, P.S., Pereira, F.H.F., Santos, R.V., Lima, G.S. 2012. Crescimento e respostas fisiológicas de espécies arbóreas em solo salinizado tratado com corretivos. Revista Brasileira de Engenharia Agrícola e Ambiental 16: 173-181.

Souza, M.C.M.R., Lacerda, C.F., Amorim, A.V., Menezes, A.S. 2014. Influência da matéria orgânica e do ambiente no crescimento e acúmulo de solutos em Morinda citrifolia submetida à salinidade. Revista Brasileira de Fruticultura 36: 704- 712.

Stamford, N.P., Ribeiro, M.R., Cunha, K.P.V. 2007. Effectiveness of sulfur with Acidithiobacillus and gypsum in chemical attributes of a Brazilian sodic soil. World Journal Microbiology Biotechnology 23: 1433-1439.

Talei, D., Kadir, M.A., Yusop, M.K., Valdiani, A., Abdullah. 2012. Salinity effects on macro and micronutrients uptake in medicinal plant King of Bitters (Andrographis paniculata Nees.). Plant Omics Journals 5: 271-278.

Tejada, M., Garcia, C., Gonzalez, J.L., Hernandez, M.T. 2006. Use of organic amendment as a strategy for saline soil remediation: Influence on the physical, chemical and biological properties of soil. Soil Biology and Biochemistry 38: 1413-1421.

Uddin, M.D.K, Shukor, J.A., Razi, I.M., Alamgir, H., Radziah, O., Abdul, R.A. 2011. Effetc of salinity stress on nutrient uptake and chrophyll content tropical turfgrass species. Australiam Journal of Crop Science 5:620-629.

Vellini, A.L.T.T., Paula, N.F., Alves, P.L.C.A., Pavani, L. C., Bonine, C.A.V., Scarpinati, E.A., Paula, R.C. 2008. Respostas fisiológicas de diferentes clones de eucalipto sob diferentes regimes de irrigação. Revista Árvore 32:651-663.

Zia, M.H., Sabir, S.M., Ghafoor, A., Murtaza, G. 2007. Effectiveness of sulphuric acid and gypsum for the reclamation of a calcareous saline-sodic soil under four crop rotations. Journal Agronomy and Crop Science 193: 262-269. 